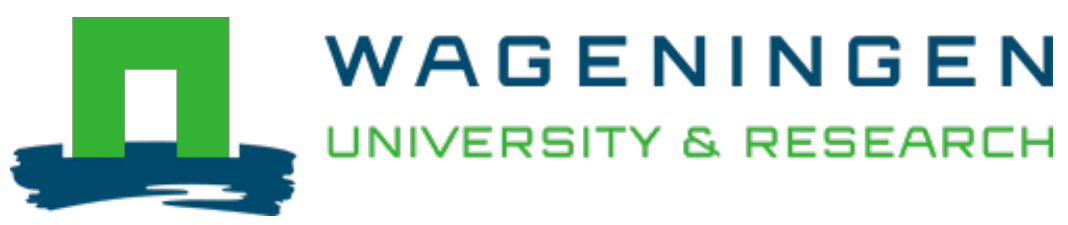

\title{
Accelerated natural lactic fermentation of cereal-based formulas at reduced water activity.
}

International Journal of Food Microbiology

Nout, M.J.R.

https://doi.org/10.1016/0168-1605(92)90033-y

This publication is made publicly available in the institutional repository of Wageningen University and Research, under the terms of article $25 \mathrm{fa}$ of the Dutch Copyright Act, also known as the Amendment Taverne. This has been done with explicit consent by the author.

Article 25 fa states that the author of a short scientific work funded either wholly or partially by Dutch public funds is entitled to make that work publicly available for no consideration following a reasonable period of time after the work was first published, provided that clear reference is made to the source of the first publication of the work.

This publication is distributed under The Association of Universities in the Netherlands (VSNU) 'Article $25 \mathrm{fa}$ implementation' project. In this project research outputs of researchers employed by Dutch Universities that comply with the legal requirements of Article $25 \mathrm{fa}$ of the Dutch Copyright Act are distributed online and free of cost or other barriers in institutional repositories. Research outputs are distributed six months after their first online publication in the original published version and with proper attribution to the source of the original publication.

You are permitted to download and use the publication for personal purposes. All rights remain with the author(s) and / or copyright owner(s) of this work. Any use of the publication or parts of it other than authorised under article $25 \mathrm{fa}$ of the Dutch Copyright act is prohibited. Wageningen University \& Research and the author(s) of this publication shall not be held responsible or liable for any damages resulting from your (re)use of this publication.

For questions regarding the public availability of this publication please contact openscience.library@wur.nl 


\title{
Accelerated natural lactic fermentation of cereal-based formulas at reduced water activity
}

\author{
M.J.R. Nout \\ Deparment of Food Science, Agricultural Unid ersity. Wageningen, The Netherlands
}

(Received 18 May 1992: accepted 2 July 1492)

Energy required to dehydrate fermented cereal-based food formulas plays a significant part in the production cost. Therefore the effect of reduced moisture content on the fermentation was investigated. Generally, lactic fermentation at reduced moisture content resulted in increased final pH. Significant acidification still occurred at $0.33 \mathrm{~kg}$ water $/ \mathrm{kg}$ dry matter corresponding to either $a_{w}=0.925$ in a sorghum-maize-soya (SMS) mixture, or $a_{w}=0.950$ in a sorghum-maize-milk powder (SMM) mixture. Acidification adequate for microbiological safety $(\mathrm{pH} \leq 4.5)$ was ichieved at $0.54 \mathrm{~kg}$ water $/ \mathrm{kg}$ $\mathrm{dm}$ in SMS $\left(a_{\mathrm{w}}=0.950\right)$ and $0.43 \mathrm{~kg} / \mathrm{kg} \mathrm{dm}$ in SMM $\left(a_{w}=0.965\right)$. In stable accelerated natural lactic fermentations obtained by inoculum recycling ('back-slopping') at $30^{\circ} \mathrm{C}$, dominant lactic acid bacteria included Lactotucilltus plantarum, $L$. bretis, $L$. acidophiles and Lactococcus lactis. Dominating yeasts were Saccharomyces ceret isiae and Candida krusei. L. plantanum isolated from high-moisture $(1.5 \mathrm{~kg} / \mathrm{kg}$ dry matter) SMS fermentations had higher specific growth rates than $L$. plantarum isolated from reduced moisture $(0.54 \mathrm{~kg} / \mathrm{kg} \mathrm{dm})$ SMS fermentations, when tested under similar $a_{w}$ conditions. This effect was not caused by previous culturing conditions; probably different strains of $L$. plantanum having different $a_{w}$-optima dominate at high or reduced moisture conditions.

Key words: Sorghum; Maize; Soya; Skim milk powder: Lactobucillus plantanum; Saccharomyces cerevisiae; Water activity

\section{Introduction}

Solid substrate fermentation of food raw material is widely applied in the preparation of c.g. koji, tempe, sourdough and fermented maize foods including kenkey (Mensah et al., 1991) and mawè (Hounhouigan et al., 1992). Solid substrate fermentation was also applied successfully in the accelerated natural lactic fermentation of infant food formulas based on cereal-legume combinations (Nout et al., 1989a,b). Accelerated fermentation employs the principle of gradual enrichment of active acidifying strains of lactic acid bacteria through the recycling of inoculum ('back-slopping'). This is a simple technique which is particularly suitable for

Correspondence address: M.J.R. Nout, Department of Food Science, Agricultural University, Bomenweg 2, 6703 HD Wageningen. The Netherlands. 
household and small-scale commercial fermentation operations with only rudimentary facilities, taking place in, c.g., developing countries.

Previous experimental work with the accelerated fermentation technique was carried out using doughs consisting of equal weights of composite cereal-legume meal and water, resulting in 55-60\% moisture content (total weight basis) or $1.2-1.6 \mathrm{~kg}$ water $/ \mathrm{kg}$ dry matter $(\mathrm{dm})$. Under these conditions the fermentation is highly effective and results in $\geq 2 \mathrm{pH}$ units acidification within $6-8 \mathrm{~h}$ at $25-30^{\circ} \mathrm{C}$. The microflora is dominated by lactic acid bacteria (Lactobacillus plantantm, $L$. acidophilus, $L$. bretis and Lactococcus lactis) with a consistent minority of yeasts (Candida and Trichosporon spp.) (Nout, 1991). For convenient storage and distribution, such fermented doughs must be dehydrated. The cost of energy required for dehydration contributes significantly to the overall cost of the product. On the basis of unpublished data, it can be estimated that at a fully occupied daily production capacity of $200 \mathrm{~kg}$ final dry product, the encrgy required to reduce the moisture content of fermented dough from $1.2 \mathrm{~kg} / \mathrm{kg} \mathrm{dm}$ to $0.05 \mathrm{~kg} / \mathrm{kg}$ represents 20-25\% of the total cost of ingredients, energy and equipment. However, with an initial moisture level of $0.5 \mathrm{~kg} / \mathrm{kg}$, drying energy represents $10-15 \%$ of the adjusted total cost. Consequently, important savings can be made if the fermentation stage is carried out at lower moisture contents.

The present investigation was carried out to test the influence of reduced moisture levels on the efficacy of accelerated natural lactic fermentation and on the growth of dominating microorganisms.

\section{Materials and Methods}

\section{Ingredients}

Ingredients included whole white sorghum (Sorghum bicolor ssp. caffrorum) and whole white 'mealy' maize (Zea mays (De Witte Molen, Meeuwen, The Netherlands), dry-dehulled yellow soya beans (Glycine max) (Kleinjan V.O.F., Rhoon, The Netherlands) and low-fat medium-heated spray-dried milk powder (CCF, Leeuwarden, The Netherlands).

\section{Preparation of formulas}

Sorghum and maize grains were cleaned dry and ground to whole-grain meals using a toothed dise mill (Condux type LV $15 \mathrm{M}$, Condux-Werk, Wolfgang bei Hanau, W-Germany). Soya beans were coarsely ground in the same mill. Formulas were designed to contain approx $13 \%(w / w)$ of metabolisable protein (Nout et al., 1989b). Formula SMS contained $370 \mathrm{~g}$ of sorghum meal, $370 \mathrm{~g}$ of maize meal and $260 \mathrm{~g}$ of soya bean meal per $1000 \mathrm{~g}$. Formula SMM consisted per $1000 \mathrm{~g}$ of $400 \mathrm{~g}$ of sorghum meal, $400 \mathrm{~g}$ of maize meal and $200 \mathrm{~g}$ of milk powder.

Accelerated natural lactic fermentation of formulas

The principle of starting a stable accelerated natural lactic fermentation was described earlier (Nout et al., 1987, 1989b). For the first fermentation cycle, a 
mixture of $100 \mathrm{~g}$ dry formula and the amount of tapwater required to achieve the desired moisture content, was incubated in a 450 - $\mathrm{ml} \mathrm{screw-capped} \mathrm{glass} \mathrm{jar} \mathrm{at} 30^{\circ} \mathrm{C}$ for $24 \mathrm{~h}$. Further fermentation cycles also lasted $24 \mathrm{~h}$ at $30^{\circ} \mathrm{C}$ and the mixtures consisted of $100 \mathrm{~g}$ dry formula, $10 \mathrm{~g}$ of the previously fermented batch and the weight of tapwater (') achieve the desired moisture content.

\section{Measurement of water relations}

Resorption isotherm data were based on the dry matter content of samples (approx. $1 \mathrm{~g}$ ) which had been equilibrated against saturated solutions of $\mathrm{LiCl}$, $\mathrm{MgCl}_{2}, \mathrm{~K}_{2} \mathrm{CO}_{3}, \mathrm{NaCl}, \mathrm{KCl}$ and $\mathrm{BaCl}_{2}$ in vacuum desiccators at $30^{\circ} \mathrm{C}$ during 1 week. Sodium azide $(0.1 \%)$ was used as a preservative. Dry matter contents were determined by vacuum oven drying at 50 or $70^{\circ} \mathrm{C}$, and by Karl Fischer titration (Mettler DL18 Karl Fischer titrator). Equilibrium Relative Air Humidity (ERH) and water activity $\left(a_{w}\right)$ of samples were measured using a Rotronic hygroscope (Rotronic AG, Zürich) and a Hygrometer Model $a_{w}$-box with measuring station EEJA (Novasina AG, Zürich), respectively.

\section{Measurement of $\mathrm{pH}$}

Sampling and determinations were as described earlier (Nout et al., 1989a).

\section{Microbiological analysis}

Samples of $10 \mathrm{~g}$ were homogenized with $90 \mathrm{ml}$ sterile peptone physiological salt solution $(1 \mathrm{~g}$ peptone, $8.5 \mathrm{~g} \mathrm{NaCl}, 1000 \mathrm{ml}$ distilled water, $\mathrm{pH} 7.0 \pm 0.2)$. Lactic acid bacteria were enumerated in pour-plates of de Man. Rogosa and Sharpe (MRS) medium (Merck No. 10661, Darmstadt, Germany) to which $12 \mathrm{~g}$ agar and 1 g natamycin ('Delvocid', Gist-Brocades, Delft, The Netherlands) were added per litre, with overlay, after incubation at $30^{\circ} \mathrm{C}$ for $3-5$ days. The content of lactobacilli was estimated in pour-plates of Rogosa agar (Oxoid CM627) with overlay, after incubation at $30^{\circ} \mathrm{C}$ for 3 days. All lactic acid bacteria from MRS with natamycin were isolated and purified on MRS agar and maintained in MRS broth. Initial confirmation and grouping of lactic acid bacteria was based on Gram stain, catalase activity, growth at 15 and $45^{\circ} \mathrm{C}$ in MRS medium, gas from glucose and fermentation of lactose, sucrosc, arabinose, sorbitol, cellobiose, fructose and mannitol added to glucose-free MRS medium. The square root of the number of colonies on the MRS agar with natamycin plate dilution chosen for enumerations were isolated and purificd. Further characterisation of lactic acid bacteria was according to Sneath et al. (1986) based on the relevant biochemical reactions obtained with the 'API 50 CHL' system (API System SA, Montalieu Vercieu, France). Enumeration of yeasts and filamentous fungi was in pour-plates of Yeast Extract Glucose (YEG) Agar (Oxoid CM545) to which $0.01 \%$ w/v filter-sterilized oxytetracyclin (Pfizer) was added (OYEG). Incubation was at $25^{\circ} \mathrm{C}$ for 5 days. Isolations and purifications of yeasts were carried out on YEG agar as described above. Yeasts were grouped according to their morphology, and ability to sporulate on either V-8 agar (V-8 vegetable juice (Campbell Soup Co.) 100 ml, bakers' yeast $40 \mathrm{~g}$, agar $2 \mathrm{~g}$, distilled water $100 \mathrm{ml}$; $\mathrm{pH}$ 6.8; malt extract agar (MEA: malt 
extract (Difco) $5 \mathrm{~g}$, agar $3 \mathrm{~g}$, dist. water $100 \mathrm{ml}$ ) or yeast malt extract agar (YMEA: malt extract $10 \mathrm{~g}$, yeast extract $4 \mathrm{~g}$, glucose $4 \mathrm{~g}$, agar $15 \mathrm{~g}$, distilled water to 1000 $\mathrm{ml}, \mathrm{pH} \pm 7.3$ ), their ability to ferment glucose, grow at $37^{\circ} \mathrm{C}$ and utilise $\mathrm{KNO}_{3}$ or lysine as sole source of nitrogen (Campbell and Duffus, 1988). Further characterisation was carried out using the 'ID 32 C' system (API System SA, Montalieu Vercieu, France).

Enterobacteriaceae were enumerated in pour-plates of Violet Red Bile Glucose (VRBG, Oxoid CM 485) medium with overlay after incubation at $37^{\circ} \mathrm{C}$ for $24 \mathrm{~h}$.

The water activity $\left(a_{w}\right)$ of diluent and microbiological media was adjusted to that of the sample by adding amounts of glycerol or sorbitol calculated according to the Norrish, equation (Norrish, 1966).

\section{Growth kinetics}

Growth curves of $L$. plantarum were measured in a conical flask containing 100 ml MRS broth, after inoculation with $1 \mathrm{ml}$ of a 24-h old MRS culture, and incubated in a water bath held at $30^{\circ} \mathrm{C}$. Growth curves of Saccharomyces cererisiae were measured in $100 \mathrm{ml}$ yeast extract glucose broth (YEGB: yeast extract $5 \mathrm{~g} / \mathrm{l}$, glucose $20 \mathrm{~g} / \mathrm{l})$ at $30^{\circ} \mathrm{C}$ after inoculation with $0.1 \mathrm{ml}$ of a $10^{-3}$ dilution of a 24-h YEGB culture. Growth was monitored as extinction values at $645 \mathrm{~nm}$ in a spectrophotometer (Beckman DU-64), or as viable count in MRS agar or YEG agar, respectively.

All experiments were carried out in duplicate; all analyses in triplicate. Mean values arc presented.

\section{Results}

As the water activities caused by addition of water prior to fermentation are of relevance in this study, only the resorption data of the water sorption isotherms of the formulas are given. Table I shows the $a_{w}$ resulting from resorption of SMS and SMM formulas at $30^{\circ} \mathrm{C}$.

The effect of the moisture content on the extent of acidification is shown in Fig. 1 (SMS) and Fig. 2 (SMM). No acidification took place in SMS at $0.25 \mathrm{~kg}$ moisture $/ \mathrm{kg} \mathrm{dm}$, but significant acidification occurred at $0.33 \mathrm{~kg} / \mathrm{kg} \mathrm{dm}$ and higher moisture contents. At all tested moisture levels, it took 4-6 daily inoculum recyclings at $10 \%$ inoculation rate, to obtain a stable extent of acidification. The $a_{\mathrm{w}}$ had a significant effect on the final $\mathrm{pH}$. Table 11 shows that in all treatments in which acidification took place, the number of lactic acid bacteria was not significantly different. Lactobacilli were the dominant group of lactic acid bacteria. Lactobacillus plantarum dominated at all tested moisture levels. $L$. bretis was found particularly at $0.33 \mathrm{~kg}$ water $/ \mathrm{kg} \mathrm{dm}$. L. acidophilus and Lactococcus lactis were present as a minority in most samples. Also, the number of yeasts was not affected by the moisture content in the range $0.33-0.82 \mathrm{~kg} / \mathrm{kg} \mathrm{dm}$. Saccharomyces cerevisiae was dominating and found in all samples, whereas Candida krusei occurred in SMM at reduced moisture levels. The Enterobacteriaceae were de- 
TABLE I

Water activity at $30^{\circ} \mathrm{C}$ of SMS a and SMM ${ }^{\circ}$ formulas at different moisture contents

\begin{tabular}{lll}
\hline $\begin{array}{l}\text { Moisture content } \\
\text { (kg water } / \text { kg dry matter) }\end{array}$ & \multicolumn{2}{l}{ Water activity $\left(a_{w}\right)$} \\
\cline { 2 - 3 } & SMS & SMM \\
\hline 0.1365 & 0.755 & \\
0.1678 & 0.845 & \\
0.2500 & 0.885 & 0.960 \\
0.3330 & 0.925 & 0.965 \\
0.4286 & 0.940 & 0.975 \\
0.5385 & 0.970 & 0.980 \\
0.6667 & 0.975 & 0.990 \\
0.8182 & 0.990 & \\
1.0000 & 0.990 & \\
1.5000 & 0.990 & \\
\hline
\end{tabular}

"SMS, sorghum-maize-scya formula (370, 370 and $260 \mathrm{~g}$ respectively, per $\mathrm{kg}$ ).

"SMM, sorghum-maize-skim milk powder formula (400, $4(10)$ and $200 \mathrm{~g}$, respectively, per $\mathrm{kg}$ ).

tectable only in fermented formulas with 0.25 and $0.33 \mathrm{~kg}$ moisture $/ \mathrm{kg} \mathrm{dm}$. At higher moisture levels, the lower $\mathrm{pH}$ values apparently caused their death.

From stabilized fermentations of SMS with $1.5 \mathrm{~kg}$ water $/ \mathrm{kg} \mathrm{dm}$ and $0.54 \mathrm{~kg}$ water $/ \mathrm{kg} \mathrm{dm}$, several isolates of $L$. plantarum were obtained and compared on the

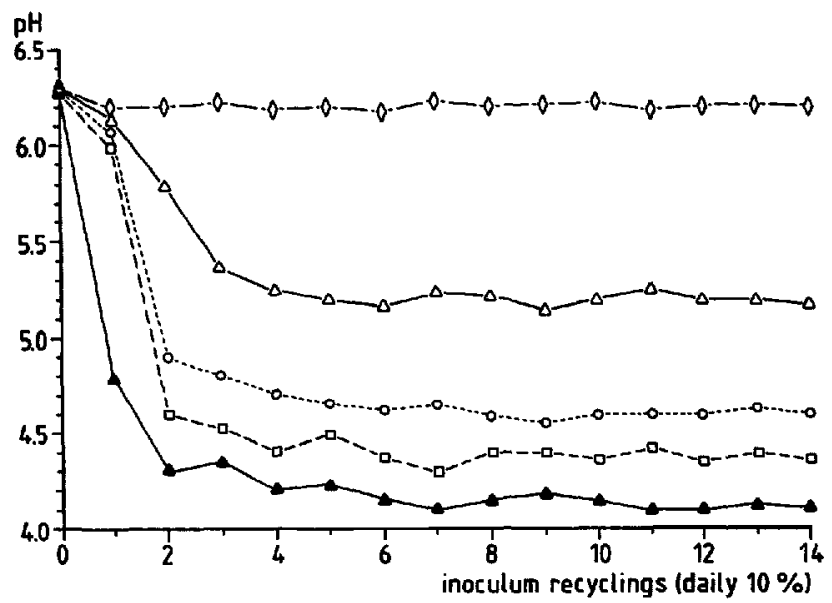

Fig. 1. Effect of moisture content on acidification in SMS formula. $\odot---\odot$, Moisture content (kg water $/ \mathrm{kg}$ dry matter) $0.25, a_{w} 0.885 ; \Delta-\Delta, 0.33,0.925 ; 0 \cdots . .0,0.43,0.940 ; \square-ー-\square$, $0.54,0.970 ; \triangle \longrightarrow, 0.82,0.990$. 


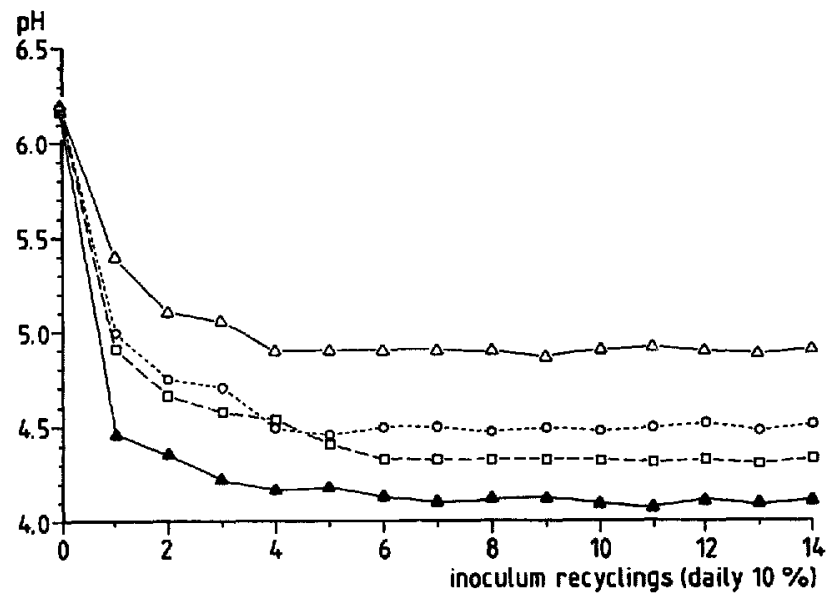

Fig. 2. Effect of movisture content on acidification in SMM formula. $\Delta-\Delta$, Moisture content (kg

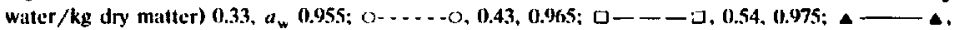
$0.82,0.9 \%)$.

basis of their profile of assimilated carbohydrates in the API50CHL test. Of these. 3 isolates with identical biochemical profiles were selected. Strain 4 had been isolated from SMS with $1.5 \mathrm{~kg}$ water $/ \mathrm{kg} \mathrm{dm}$ using MRS agar. Strains $1 \mathrm{G}$ and $1 \mathrm{~S}$ had been isolated from SMS with $0.54 \mathrm{~kg}$ water $/ \mathrm{kg} \mathrm{dm}$ using dilution liquid and MRS agar to which respectively glycerol (270 g glycerol to $1000 \mathrm{~g}$ MRS agar) and sorbitol ( $520 \mathrm{~g}$ sorbitol to $1000 \mathrm{~g}$ MRS agar) had been added to achieve $a_{w} 0.947$, i.e. comparable to the low-moisture SMS from which they originated. None of these strains were able to assimilate glycerol or sorbitol as a C-source, when added to sugar-free MRS broth. Fig. 3 shows the growth curves of these strains on MRS broth, MRS + sorbitol (MRSS; $a_{w}$ 0.947) and MRS + glycerol (MRSG; $a_{w}$ 0.947). Although quite similar optical densities were finally reached in the stationary phase, strain 4 always had a higher growth rate in the logarithmic phase. In addition, glycerol had a stronger inhibitory effect than sorbitol at $a_{w} \mathbf{0 . 9 4 7}$. In order to assess whether this effect was due to the different previous cultivation history of these cultures, strain 4 was grown under different conditions by sub-culturing thrice in MRS, MRSS and MRSG. Subscquently, the pre-cuitured cells were inoculated into MRS, MRSS and MRSG. No significant influence of previous history of strain 4, on its growth rate in MRS, MRSS or MRSG were observed (data not included). The inhibitory effect of glycerol was again stronger than that of sorbitol.

Similarly, isolates of Saccharomyces cerevisiae were obtained from SMS with 1.5 $\mathrm{kg}$ water $/ \mathrm{kg} \mathrm{dm} \mathrm{(strain} \mathrm{'} \mathrm{O}$ ' isolated on OYEG agar) and SMS with $0.54 \mathrm{~kg}$ 


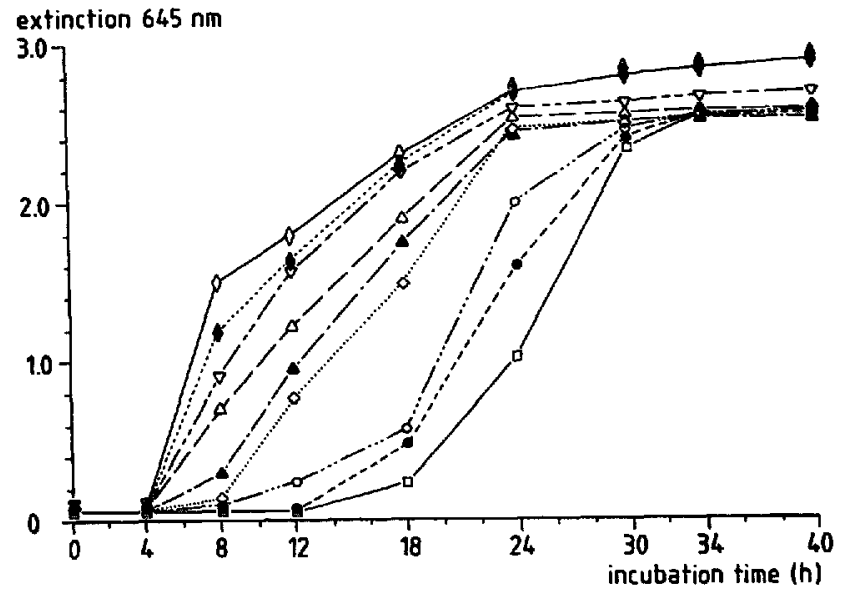

Fig. 3. Growth of Lackobacillus phonurum isolates of different origin. $\diamond->$, Lackobacillus plantarum strain 4, grow1h medium MRS: $\triangle---\Delta$, strain 4, growth medium MRSS (MRS + sorbitol added to $\left.a_{w}=0.945\right) ; 0-\cdots, 0$, strain 4, growth medium MRSG (MRS + glycerol added to $a_{w}=$ 0.945); $\ldots . . \bullet$, strain 1G, growth medium MRS; $\_-\cdots \bullet$, strain 1G, growth medium MRSS; - - - strain IG, growth medium MRSG: $\nabla-\cdots-\nabla$. strain 1S. growth medium MRS; ○.... $\diamond$, strain 1S, growth medium MRSS: $\square-\square$, strain IS, growth medium MRSG.

water $/ \mathrm{kg} \mathrm{dm}$ (strains 'O-G' and ' $O-S$ ' isolated on OYEG agar with addition of glycerol or sorbitol, respectively, to give $a_{w}$ 0.945). The growth of the isolates mentioned having identical biochemical profiles with the ID32C test was monitored on YEG broth (YEGB; $a_{w}$ ca. 1.0), YEG broth + glycerol (YEGBG; $a_{w}$ 0.947) and YEG broth + sorbitol (YEGBS; $a_{w}$ 0.947). The growth rate of the respective isolates on each of the media did not differ significantly (results not shown). However, in contrast to the L. plantarum isolates, Sacch. cerevisiae was more strongly inhibited by sorbitol than by glycerol at the same $a_{w}$ (results not shown).

\section{Discussion}

The resorption data shown in Table I are of the order of magnitude of those reported of cereals and pulses (Krischer and Kast, 1978; Jowitt et al., 1983). However, most published sorption isotherms are less reliable at $a_{w}>0.97$ (Jowitt et al., 1983). SMS was less hygroscopic compared with SMM. Consequently, if skim milk powder is available at reasonable cost, it will have the economic advantage that the fermentation can take place at lower moisture levels than in SMM formula. 
TABLE II

Microbiological content of SMS " and SMM a formulas before fermentation and after stabilized accelerated natural lactic fermentation at different moisture contents

\begin{tabular}{|c|c|c|c|c|}
\hline & $\begin{array}{l}\text { Lactic acid } \\
\text { bacteria }\end{array}$ & Lactobacilli & Yeasts & $\begin{array}{l}\text { Eiticrio- } \\
\text { bacteriaceae }\end{array}$ \\
\hline \multicolumn{5}{|l|}{ SMS formula: } \\
\hline Unfermented, dry & $2.8^{\mathrm{h}}$ & 2.3 & 3.2 & 2.4 \\
\hline \multicolumn{5}{|l|}{ Fermented ${ }^{\mathrm{C}}$ at: } \\
\hline $0.25 \mathrm{~kg}$ water $/ \mathrm{kg} \mathrm{dm}$ & 3.11 & 2.30 & 5.65 & 2.73 \\
\hline $0.33 \mathrm{~kg}$ water $/ \mathrm{kg} \mathrm{dm}$ & 9.32 & 9.33 & 7.25 & 3.97 \\
\hline $0.43 \mathrm{~kg}$ water $/ \mathrm{kg} \mathrm{dm}$ & 9.78 & 9.77 & 7.62 & $<1.7$ \\
\hline $0.54 \mathrm{~kg}$ water $/ \mathrm{kg} \mathrm{dm}$ & 9.48 & 9.65 & 7.14 & $<1.7$ \\
\hline $0.82 \mathrm{~kg}$ water $/ \mathrm{kg} \mathrm{dm}$ & 9.85 & 9.87 & 7.44 & $<1.7$ \\
\hline \multicolumn{5}{|l|}{ SMM formula: } \\
\hline Unfermented, dny & 2.3 & 2.0 & 3.1 & 3.6 \\
\hline \multicolumn{5}{|l|}{ Fermented ${ }^{c}$ at: } \\
\hline $0.33 \mathrm{~kg}$ water $/ \mathrm{kg} \mathrm{dm}$ & 9.34 & 9.36 & 6.47 & 2.19 \\
\hline $0.43 \mathrm{~kg}$ water $/ \mathrm{kg} \mathrm{dm}$ & 9.60 & 9.61 & 6.92 & $<1.7$ \\
\hline $0.54 \mathrm{~kg}$ water $/ \mathrm{kg} \mathrm{dm}$ & 9.39 & 9.61 & 6.85 & $<1.7$ \\
\hline $0.82 \mathrm{~kg}$ water $/ \mathrm{kg} \mathrm{dm}$ & 9.48 & 9.72 & 6.95 & $<1.7$ \\
\hline
\end{tabular}

"For explanation see Table !.

- $\log _{10} \mathrm{Ng}^{-1}$.

- 7 daily recyclings at $10 \%$ inocuiation rate, incubated at $30^{\circ} \mathrm{C}$.

A major reason for fermenting mixtures of cereals and legumes is to improve the micr obiological safety of weaning foods. Dehydration of the fermented product is rejuited for convenient packaging, shelf-life and distribution. In view of the relatively high cost of thermal energy required for dehydration, the fermentation should be carried out at a minimum effective moisture level. A $\mathrm{pH} \leq 4.5$ is regarded as essential to ensure the inhibition or death of undesired bacteria and to prevent the germination of spores from pathogenic Bacillaceae. From the results in Figs. 1 and 2 it may be concluded that in the tested mixtures, the above requirement is achieved at $0.43 \mathrm{~kg}$ water $/ \mathrm{kg} \mathrm{dm}$ in $S M M$, and at $0.54 \mathrm{~kg} / \mathrm{kg} \mathrm{dm}$ in SMS. Compared with fermentations at a relatively high moisture level $(1.5 \mathrm{~kg} / \mathrm{kg}$ $\mathrm{cm}$ ), the reduction of the moisture content did not significantly affect the levels of functional microflora (mainly lactic acid bacteria).

At all tested moisture levels, $L$. plantarum was the dominating species of lactic acid bacteria. The minimum $a_{w}$ enabling growth of microorganisms depends on many factors, including the nature of the $a_{w}$ controlling solute (Brown, 1976) and the pH (Farkas et al., 1988). Suppressed with $\mathrm{NaCl}$, the minimum $a_{w}$ for growth of L. plantarum is 0.94-0.97 (Imhoff, 1986; Farkas et al., 1988) but with glycerol it is 0.885-0.915 (Rchacek et al., 1982; Imhoff, 1986). Fig. 1 and Table II show that at $a_{w} 0.883$ (in SMS formula) no appreciable growth or acidification occurred.

Although our $L$. plantarum strains did not assimilate sorbitol, the species is listed as sorbitol-positive (Sneath et al., 1986) and consequently sorbitol must enter 
the cell. However, the transport mechanism of sorbitol into cells of lactobacilli has not been reported. The consistent difference in growth rate between sorbitol- and glycerol-depressed $a_{w}$ in MRS (Fig. 3) must be caused at intracellular level. Either glycerol has a specific inhibitory effect, or sorbitol acts as an osmoprotectant or compatible solute. At $a_{\mathrm{w}}$ near to 1.0 (MRS) and $a_{\mathrm{w}}$ (0.945 (MRSG; MRSS), $L$. plantarum strain 4 isolated from SMS with $1.5 \mathrm{~kg}$ moisture $/ \mathrm{kg} \mathrm{dm}$ had a higher growth rate than $L$. plantarum strains $1 G$ and $1 S$ isolated from SMS with $0.54 \mathrm{~kg}$ moisture $/ \mathrm{kg} \mathrm{dm}$. This effect was not caused by previous culturing conditions. Consequently, we suggest that biochemically identical strains of $L$. plantanum may still be different on the basis of their growth rate and that high moisture levels enable the enrichment of such relatively fast-growing strains.

Lowering the moisture content in the forisulas did not affect yeast growth except at $a_{w} 0.883$ in SMS. In any case, Sacch. cer orisiue is able to grow at lower $a_{w}$ than $L$. plantarum. With $a_{w}$ adjusted with glıcose $a_{w} \geq 0.89$ was required for growth (Cerrutti et al., 1990), but with glycerol $a_{w} \geq 0.80$ was reported (Rehacek et al., 1982).

A possible risk of extreme reduction of moistu e levels in fermenting formulas is that yeasts will outnumber lactobacilli. Table II shows that this happens indeed at $0.25 \mathrm{~kg}$ water $/ \mathrm{kg} \mathrm{dm}$ in SMS. However, this mois ure level is of less relevance since it does not achieve the aim of acidification. At all higher moisture contents tested, yeasts represented less than $1 \%$ of the number of lactobacilli.

\section{Acknowledgements}

The author gratefully acknowledges the collaboration of P. Tanis, M. Mouwen, R. Müller and H.M. Bouwmeester, Department of Food Science, Agricultural University, Wageningen.

\section{References}

Brown, A.D. (1976) Microbial water stress. Bacteriol. Rev, 40, 803-846.

Campbell, I. and Duffus, J.H. (I988) Yeast. A Practical Approsach. IRL Press Lud, Oxford, UK.

Cerrutti. P., Alzamorit. S.M. and Chirife, J. (1990) A multi-parameter approach to control the growth of Saccharomyces cerretisiale in lahoratory media. J. Food Sci. 55, 837-840.

Farkas Mohacsi. Cs. Veinperl Toth. I. and Toth. M. (1988) Investigation of the growth inhibition and heat stability of Lactobacilli in function of $\mathrm{nH}$ and water activity values. In: Proceedings of the International Symposium on 'Progress in Food Preservition Processes' organized by CERIA (Centre for Education and Research of Finul ard Chemical Industries). Brussels. Belgium, 12-14 April 1988. pp. 129-135.

Hounhouigan, D.J., Nou, M.J.R., Nago, C.M.. Houben, J.H. und Rombouts. F.M. (1992) Production and quality characteristics of mawé, a fermented maize dough from Bénin. Int. J. Food Sci. Technol., in press.

Imhoff, J.F. (1986) Osmoregulation and compatible solutes in eubacteria. FEMS Microbiol. Rev. 39, 57-66.

Jowitt. R., Escher, F., Hallström. B.. Meffert. H.F.Th.. Spiess. W.E.L. and Vos, G. (Eds.) (1983) Physical Properties of Foxds. Applied Science Publishers, London, pp. 13-102. 
Krischer, O. and Kast, W. (1978) Die Wissenschafilichen Grundlagen der Trocknungstechnik. Springer Verlag. Berlin.

Mensah, P. Tomkins, A.M., Drasar, B.S. and Harrison, T.J. (1991) Antimicrobial effect of fermented Ghanaian maize dough. J. Appl. Bacteriol. 70, 203-210.

Neidhardt, F.C., Ingraham, J.L. and Schaechter, M. (1990) Physiology of the Bacterial Cell. Sinauer Assuciates, Inc., Sunderland.

Norrish, R.S. (1966) An equation for the activity coefficient and equilibrium relative humidities of water in confectionary syrups. J. Fond Technol. 1, 25-39.

Nout, M.J.R. (1991) Ecology of accelerated natural lactic fermentation of sorghum-based infant food formulas. Int. J. Foxd Microbiul. 12, 217-224.

Nout, M.J.R., De Dreu, M.A., Zuurbier, A.M. and Bonants-Van Luarhoven. T.M.G. (1987) Ecology of controlled soyabean acidification for tempe manufacture. Food Microbiol. 4, 165-172.

Nout, M.J.R., Rombouts, F.M. and Havelaar, A. (1989a) Effect of accelerated natural lactic fermentation of infant food ingredients on some pathogenic micro-organisms. Int. J. Food Microbiol. 8, $35 !-361$.

Nout, M.J.R., Rombouts. F.M. and Hautvast, G.J. (1989b) Accelerated natural lactic fermentation of infant food formulations. Food Nutrit. Bull. U.N.U. 11, 65-73.

Rehacek, J., Sozzi, T. and Stider, P. (1982) Effect of water activity on the development of lactic acid bacteria and yeast utilized in the food industry. Milchwissenschaft 37, 151-154.

Sneath, P.I1.A., Mair. N.S., Sharpe, M.E. and Holt, J.G. (1986) Bergey's Manual of Systematic Bacteriology. Volume 2. Williams and Wilkins, Baltimore. 